\title{
1 Income-based Greenhouse Gas Emissions of Nations
}

2 Sai Liang ${ }^{1, *}$, Shen Qu ${ }^{1}$, Zeqi Zhu ${ }^{1}$, Dabo Guan ${ }^{2}$, Ming Xu ${ }^{1,3, *}$

$3{ }^{1}$ School of Natural Resources and Environment, University of Michigan, Ann Arbor, Michigan 48109-

4 1041, United States

$5 \quad{ }^{2}$ School of International Development, University of East Anglia, Norwich, NR4 7TJ, UK

$6{ }^{3}$ Department of Civil and Environmental Engineering, University of Michigan, Ann Arbor, Michigan

7 48109-2125, United States

8

9

$10 *$ To whom correspondence should be addressed.

11 Email: liangsai@umich.edu (Sai Liang); mingxu@umich.edu (Ming Xu).

12 Phone: +1-734-763-8644; fax: +1-734-936-2195.

13

14 


\section{ABSTRACT}

Accounting for greenhouse gas (GHG) emissions of nations is essential to understanding their importance to global climate change and help inform the policymaking on global GHG mitigation. Previous studies have made efforts to evaluate direct GHG emissions of nations (a.k.a. production-based accounting method) and GHG emissions caused by the final consumption of nations (a.k.a. consumption-based accounting method), but overlooked downstream GHG emissions enabled by primary inputs of individual nations and sectors (a.k.a. income-based accounting method). Here we show that the income-based accounting method reveals new GHG emission profiles for nations and sectors. The rapid development of mining industries drives income-based GHG emissions of resourceexporting nations (e.g., Australia, Canada, and Russia) during 1995-2009. Moreover, the rapid development of sectors producing basic materials and providing financial intermediation services drives income-based GHG emissions of developing nations (e.g., China, Indonesia, India, and Brazil) during this period. The income-based accounting can support supply-side policy decisions and provide additional information for determining GHG emission quotas based on cumulative emissions of nations and designing policies for shared responsibilities.

30

TOC

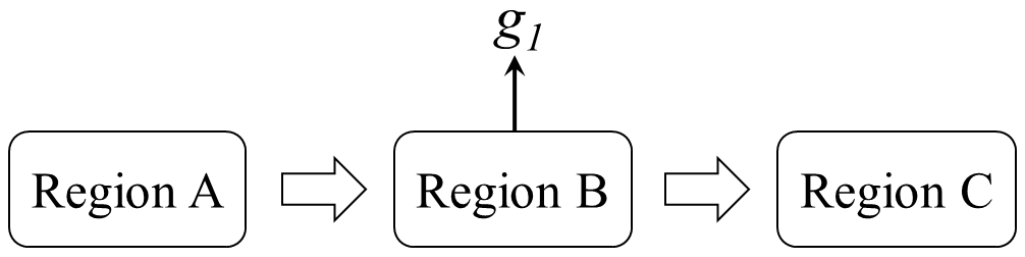

\begin{tabular}{|l|ccc|}
\hline Accounting methods & Region A & Region B & Region C \\
\hline Production-based & 0 & $g_{1}$ & 0 \\
Consumption-based & 0 & 0 & $g_{1}$ \\
Income-based & $g_{1}$ & 0 & 0 \\
\hline
\end{tabular}




\section{INTRODUCTION}

Accounting for greenhouse gas (GHG) emissions of nations is essential to understanding their contributions to and responsibilities for global climate change and inform the policymaking on global GHG mitigation. Existing studies focus on the accounting of GHG emissions of nations. The United Nations Framework Convention on Climate Change (UNFCCC) is based on GHG emissions of nations according to their direct geographic GHG emissions (e.g., region B in Figure 1) ${ }^{1}$, a.k.a. productionbased accounting method $\stackrel{2}{2}$. The production-based accounting method neglects indirect GHG emissions embodied in the supply chain, causing carbon leakage which undermines the effects of international

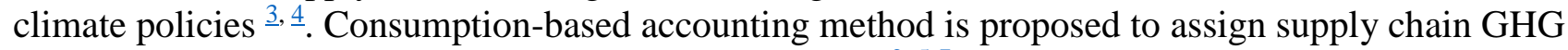

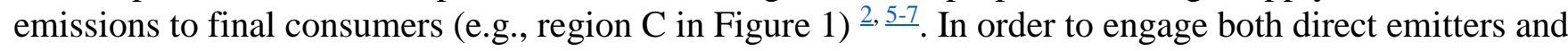
final consumers in global GHG mitigation, studies have suggested that nations/regions should share production-based and consumption-based emission responsibilities $\stackrel{2,}{2-10}$.

On the other hand, economies can be regarded as not only demand-driven (corresponding to the consumption-based accounting method) but also supply-driven $\underline{11}, \underline{12}$. Primary inputs (e.g., supplies of labor forces and capital) at the beginning of supply chains enable the production and GHG emissions of downstream users. Production-based and consumption-based accounting methods overlook the role of primary inputs in global supply chains.

To highlight the role of primary inputs in global supply chains, income-based accounting method has been proposed as an alternative approach to allocate global GHG emissions to nations. It assigns global emissions to primary suppliers (e.g., region A in Figure 1) that enable downstream emissions through primary inputs $\stackrel{13-16}{ }$. Identifying critical primary suppliers can help inform supply-side policymaking such as influencing product allocation behaviors (e.g., encouraging mining enterprises to sell resources to downstream users that have low GHG intensity) and primary input behaviors (e.g., properly limiting loan supply and subsidies to mining enterprises that have large income-based GHG emissions) $\underline{17}, \underline{18}$, which are different from production-side (corresponding to the production-based accounting method) and demand-side (corresponding to the consumption-based accounting method) policies.

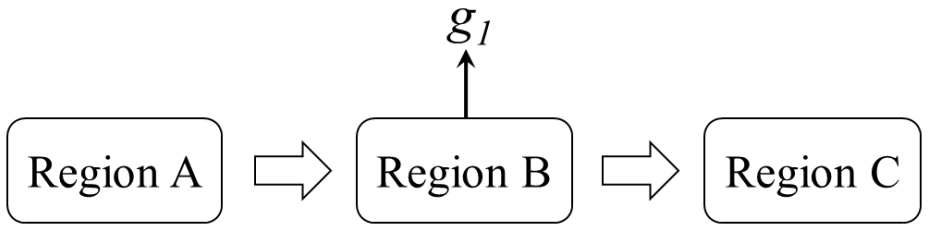

\begin{tabular}{|l|ccc|}
\hline Accounting methods & Region A & Region B & Region C \\
\hline Production-based & 0 & $g_{1}$ & 0 \\
Consumption-based & 0 & 0 & $g_{1}$ \\
Income-based & $g_{1}$ & 0 & 0 \\
\hline
\end{tabular}

Figure 1. A three-region economy showing the production-based, consumption-based, and incomebased accounting methods. Region B have $g_{l}$ direct emissions, while regions $\mathrm{A}$ and $\mathrm{C}$ do not have direct emissions. Region A supplies to the production of region B, and region B supplies to the final consumption of region C. Region B is identified as important based on the production-based accounting; region $\mathrm{C}$ is identified as important based on the consumption-based accounting; and region $\mathrm{A}$ is identified as important based on the income-based accounting. 
In addition, existing studies on income-based GHG emissions of nations are limited to carbon dioxide emissions based on data for a specific year (i.e., $2001 \stackrel{13}{\text {, }} 2004 \stackrel{14}{\text {, and }} 2011^{16}$ ). A time-series analysis of income-based GHG emissions of nations can examine historical trends and thereby allow for an understanding of the dynamics of GHG emissions resulting from each nation's primary inputs. Moreover, existing studies on income-based GHG emissions are at the national level, instead of the nation-sector level which can support supply-side, sector-specific policymaking for global GHG mitigation.

In this study we constructed a time-series GHG emission inventory of nations during 1995-2009 using income-based accounting method. We first examined income-based GHG emissions of nations. We then identified key nation-sectors in income-based GHG emissions. We also compared historical trends of nations in income-based, production-based, and consumption-based GHG emissions. We found that the income-based accounting reveals new profiles for GHG emissions of nations and sectors. In addition, GHG emissions considered in this study cover carbon dioxide, methane, and nitrous oxide, instead of just carbon dioxide in previous studies.

\section{METHODS AND DATA}

Production-based accounting investigates a nation's role as a direct emitter, and production-based GHG emissions of a nation mean its direct geographic GHG emissions. Consumption-based accounting investigates a nation's role as a final consumer, and consumption-based GHG emissions of a nation mean both direct and indirect upstream GHG emissions caused by its final consumption. Income-based accounting investigates a nation's role as a primary supplier, and income-based GHG emissions of a nation mean both direct and indirect downstream GHG emissions enabled by its primary inputs. This study uses a global environmentally extended multiregional input-output (EE-MRIO) model to evaluate production-based, consumption-based, and income-based GHG emissions of nations.

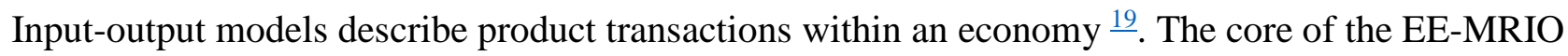
model is a multiregional input-output (MRIO) table describing product exchanges within and among nations 20,21 . GHG emissions of sectors are treated as the satellite account of the MRIO table. The EEMRIO model traces GHG emissions from the nation of final consumption (i.e., final consumers) to the nation of production (i.e., producers) by capturing product supply chains $\underline{15}, \underline{20}, \underline{21}$. It also traces GHG emissions from the nation of primary inputs (i.e., primary suppliers) to the nation of production (i.e., producers) by capturing product sale chains $\stackrel{13-15}{\text {. }}$.

Production-based (equation 1), consumption-based (equation 2), and income-based (equation 3) GHG emissions of nations can be measured by equations (1) to (3)

$p_{r}=e^{\prime} x_{r}$

$c_{r}=e^{\prime}(\mathrm{I}-\mathrm{A})^{-1} f_{r}$

$i_{r}=v_{r}(\mathrm{I}-\mathrm{B})^{-1} e$

where $p_{r}, c_{r}$, and $i_{r}$ indicate production-based, consumption-based, and income-based GHG emissions of nation $r$, respectively. The column vector $e$ represents GHG emissions by unitary output of sectors, which equals to GHG emissions of each sector divided by its total output. The notation ' means the transposition of the vector $e$. The column vector $x_{r}$ indicates the total output of each sector in nation $r$; the column vector $f_{r}$ indicates the final demand of nation $r$; and the row vector $v_{r}$ indicates the primary input of each sector in nation $r$. The matrix I is an identify matrix. The block matrix A shown in 
equation (4) is the direct input coefficient matrix, and the block matrix B shown in equation (5) is the direct output coefficient matrix. The block $\mathrm{A}^{\mathrm{rs}}$ shows direct purchases from sectors of nation $r$ by unitary output of each sector in nation $s$. The block $\mathrm{B}^{\text {rs }}$ shows direct sales from sectors of nation $r$, in terms of unitary output in each sector of nation $r$, to sectors in nation $s$.

$\mathrm{A}=\left(\begin{array}{ccccc}\mathrm{A}^{11} & \ldots & \mathrm{A}^{1 \mathrm{~s}} & \ldots & \mathrm{A}^{\mathrm{ln}} \\ \ldots & \ldots & \ldots & \ldots & \ldots \\ \mathrm{A}^{\mathrm{r} 1} & \ldots & \mathrm{A}^{\mathrm{rs}} & \ldots & \mathrm{A}^{\mathrm{rn}} \\ \ldots & \ldots & \ldots & \ldots & \ldots \\ \mathrm{A}^{\mathrm{n} 1} & \ldots & \mathrm{A}^{\mathrm{ns}} & \ldots & \mathrm{A}^{\mathrm{nn}}\end{array}\right)$

$\mathrm{B}=\left(\begin{array}{ccccc}\mathrm{B}^{11} & \ldots & \mathrm{B}^{1 \mathrm{~s}} & \ldots & \mathrm{B}^{1 \mathrm{n}} \\ \ldots & \ldots & \ldots & \ldots & \ldots \\ \mathrm{B}^{\mathrm{r} 1} & \ldots & \mathrm{B}^{\mathrm{rs}} & \ldots & \mathrm{B}^{\mathrm{rn}} \\ \ldots & \ldots & \ldots & \ldots & \ldots \\ \mathrm{B}^{\mathrm{n} 1} & \ldots & \mathrm{B}^{\mathrm{ns}} & \ldots & \mathrm{B}^{\mathrm{nn}}\end{array}\right)$

The matrix $(\mathrm{I}-\mathrm{A})^{-1}$, regarded as the Leontief Inverse matrix, captures the effect of global supply chains by describing both direct and indirect inputs from various sectors required to satisfy unitary final demand of products from particular sectors. The matrix $(\mathrm{I}-\mathrm{B})^{-1}$, regarded as the Ghosh Inverse matrix, captures the effect of global sale chains by describing both direct and indirect outputs from various sectors enabled by unitary primary input of particular sectors.

Leontief MRIO model is regarded as demand-pull. Changes in the final demand drive upstream outputs $\underline{22}$. On the other hand, Ghosh MRIO model is regarded as supply-push. Changes in primary inputs (e.g., labor and capital) drives downstream outputs $\stackrel{22}{2}$. This study uses the Leontief MRIO model to capture the effect of global product supply chains in a particular year, which is the basis of consumption-based accounting. It also uses the Ghosh MRIO model to capture the effect of global product sale chains in a particular year, which is the basis of income-based accounting. In essence, the consumption-based accounting allocates emissions to final consumers, while the income-based accounting attributes emissions to primary suppliers.

In particular, the income-based accounting method is different from the extraction-based accounting method $\stackrel{23}{ }$ on two fronts. First, the extraction-based accounting method traces emissions back to the point of fuel extraction, while the income-based accounting method traces emissions back to primary inputs (e.g., labor forces and capital). In other words, the extraction-based accounting method only examines fuel extraction sectors and fuel supply chains, while the income-based accounting method examines all sectors and full product sale chains. Second, the extraction-based accounting method only considers GHG emissions from fuel combustion, while the income-based accounting method takes into account all types of GHG emission sources (e.g., fuel combustion, industrial processes, agricultural activities, and waste disposal activities). This study finds that although the income-based and extractionbased accounting methods can both identify mining as a critical sector, the income-based accounting method can also identify other critical sectors (e.g., financial intermediation, agriculture, and wholesale $\&$ commission) that cannot be identified by the extraction-based accounting method. 
Data for MRIO tables and GHG emissions of sectors are from the World Input-Output Database (WIOD, released on November 2013) during 1995-2009. The WIOD divides the world into 41 nations/regions and 1,435 nation-sectors (35 sectors per nation) for each year $\underline{24}, \underline{25}$. GHG emissions considered in this study cover carbon dioxide, methane, and nitrous oxide, instead of just carbon dioxide in previous studies. Carbon dioxide equivalent $\left(\mathrm{CO}_{2}-\mathrm{e}\right)$ values of carbon dioxide, methane, and nitrous oxide are from the Fifth Assessment Report of the Intergovernmental Panel on Climate Change ${ }^{26}$. The population and gross domestic products (GDP, in constant 2011 international dollars) of nations used to normalize their GHG emissions are from the World Bank database ${ }^{27}$, except for Taiwan which is not separately listed in the World Bank database. The population and GDP of Taiwan are from its statistical departments $\stackrel{28}{2}$. In particular, data for China in the World Bank database do not include Hong Kong and Macau, while data for China in the WIOD database cover Hong Kong and Macau. We sum up data for China, Hong Kong, and Macau in the World Bank database to be consistent with the system boundary of the data for China in the WIOD database.

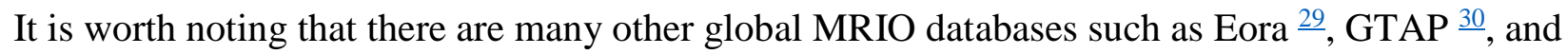
EXIOPOL $\underline{31}$. Scholars observed significant differences in data quality among these databases $\underline{32-34}$ and are trying to find ways to harmonize them $\underline{35}, \underline{36}$. Future studies based on global MRIO databases will greatly benefit from the harmonization in the data quality of these global MRIO databases. Moreover, given that sector and nation aggregation in input-output (IO) data can affect results of IO analyses $\frac{37-41}{\text {, }}$ it is an interesting future research avenue to improve sector and nation resolution of the WIOD data.

\section{CUMULATIVE INCOME-BASED GHG EMISSIONS OF NATIONS}

China is the largest contributor to global GHG emissions in 2009. Its production-based, consumptionbased, and income-based GHG emissions in 2009 are 8.6, 8.2, and 7.8 billion tonnes of $\mathrm{CO}_{2}$ equivalents (Bt $\mathrm{CO}_{2}-\mathrm{e}$ ), respectively, which are 62\%, 44\%, and 44\% higher than GHG emissions of the US in 2009 (Figure S1). However, the US has the largest cumulative GHG emissions during 1995-2009. Its cumulative production-based, consumption-based, and income-based GHG emissions during 1995-2009 are 85.9, 92.3, and $86.9 \mathrm{Bt} \mathrm{CO}_{2}-\mathrm{e}$, respectively, which are $1 \%, 16 \%$, and $13 \%$ higher than cumulative GHG emissions of the second contributor-China during this period (Figure $2 \mathrm{~A}$ ).

The income-based accounting method reveals different GHG emission profiles of nations over the production-based and consumption-based accounting methods. Russia, a major contributor to global GHG emissions, is more important as a primary supplier than as a direct emitter or final consumer of GHG emissions. It is a major exporter of resources (e.g., timber, mineral ores, and fossil fuels) which are essential inputs to industrial production. Resource extraction and exports of Russia enable downstream production and large amounts of GHG emissions (e.g., in electricity generation and metal smelting) (Figure S2). Cumulative income-based GHG emissions of Russia are 57\% and 4\% higher than its consumption-based and production-based GHG emissions during 1995-2009, respectively (Figure 2A). We observe similar situation for GHG emissions of another two resource-exporting nations: Australia and Canada (Figures 2A and S2). Thus, the income-based accounting method highlights the important roles of resource-exporting nations as primary suppliers for global GHG emissions. If global GHG reduction takes into account income-based GHG emissions of nations, in addition to their production-based and consumption-based GHG emissions, resource-exporting nations will share more responsibilities. This finding also informs that supply-side measures should pay more attention to resource-exporting nations. 
On the other hand, we observe the opposite situation for resource-importing nations. Cumulative income-based GHG emissions of the US-the biggest contributor to global cumulative GHG emissionsare 6\% lower than its cumulative consumption-based GHG emissions during 1995-2009. Moreover, cumulative income-based GHG emissions of China-the second biggest contributor to global cumulative GHG emissions-are 9\% and 3\% lower than its cumulative production-based and consumption-based GHG emissions during 1995-2009, respectively (Figure 2A). These nations are major resource importers and locate in downstream stages of global supply chains. They are more important as producers or final consumers than as primary suppliers. If global GHG reduction takes into account income-based GHG emissions of nations, in addition to their production-based and consumption-based GHG emissions, resource-importing nations will probably share less responsibilities. Such findings highlight the additional insights afforded by the income-based accounting method in relation to nations' roles in driving global GHG emissions. Demand-side measures should pay more attention to resourceimporting nations.

Developed nations generally have smaller populations with better life quality than developing nations. Therefore, per capita cumulative GHG emissions of developed nations are generally larger than those of developing nations (Figure 2B). Luxembourg (414 t CO 2 -e / capita) and Australia (389 t CO 2 -e / capita) are the two largest countries in per capita cumulative income-based GHG emissions, while India (21 t $\mathrm{CO}_{2}$-e / capita) and Indonesia (33 $\mathrm{t} \mathrm{CO}_{2}$-e / capita) are the two smallest.

Moreover, developed nations usually command more advanced and environmental friendly technologies, and are subject to stricter environmental regulations than developing nations. Thus, per gross domestic products (GDP) GHG emissions of developed nations are generally smaller than those of developing nations (Figure 2C). Russia (967 $\mathrm{g} \mathrm{CO}_{2}$-e / US\$) and China (807 $\mathrm{g} \mathrm{CO}_{2}$-e / US\$) has the largest per GDP income-based GHG emissions (Figure 2C), as a large portion of their primary inputs are given to sectors producing basic materials (e.g., agriculture, mining, fossil fuel processing, metal production, and electricity generation) and services which also enable large downstream GHG emissions (Figure S2).

Levels of nations' importance as drivers of global GHG emissions change substantially within the income-based, production-based, and consumption-based accounting methods. For instance, Russia has the largest per GDP production-based (933 $\mathrm{g} \mathrm{CO}_{2}-\mathrm{e} / \mathrm{US} \$$ ) and income-based (967 $\mathrm{g} \mathrm{CO}_{2}$-e / US\$) GHG emissions, while China has the largest per GDP consumption-based GHG emissions $\left(829 \mathrm{~g} \mathrm{CO}_{2}\right.$-e / US\$) during 1995-2009.

\section{CUMULATIVE INCOME-BASED GHG EMISSIONS OF NATION-SECTORS}

Results at the sector level (Figure 3) show that top 20 sectors in income-based GHG emissions during 1995-2009 are mainly related to basic materials (i.e., agriculture, mining, metals, and electricity) and manufacture-related services (i.e., renting and other business, wholesale and commission trade, financial intermediation, inland transport, and other services). Basic materials and these services are essential to industrial production and enable large amounts of downstream GHG emissions. These sectors mainly locate in nations with large GDP, i.e., the US, China, India, Russia, and Brazil.

The income-based accounting method reveals different importance degrees of nation-sectors over the production-based and consumption-based accounting methods. Three sectors of the US (i.e., renting and other business, wholesale and commission trade, and financial intermediation) have relatively few production-based and consumption-based GHG emissions, but large income-based GHG emissions. For 
instance, income-based GHG emissions of renting and other business sector of the US are 389\% and $554 \%$ higher than its production-based and consumption-based emissions, respectively. These three sectors are more important as primary suppliers than as direct emitters and final consumers. They provide essential services to downstream producers and enable large amounts of downstream GHG emissions.

Moreover, the income-based accounting method gives different sector rankings compared to the production-based and consumption-based accounting methods. For instance, the mining sector of China ranks the $163^{\text {rd }}$ in cumulative consumption-based GHG emissions, but the $6^{\text {th }}$ in cumulative incomebased GHG emissions during 1995-2009. Moreover, the financial intermediation sector of the US ranks $119^{\text {th }}$ in cumulative production-based GHG emissions, but $15^{\text {th }}$ in cumulative income-based GHG emissions during 1995-2009.

These findings are validated by the relatively low correlation among the sector rankings by cumulative production-based, consumption-based, and income-based GHG emissions (Table S1). The correlation coefficient for sector rankings by cumulative income-based and production-based GHG emissions is 0.7 , and that by cumulative income-based and consumption-based GHG emissions is 0.6. Both of the correlation coefficients are a little far from 1 which indicates the same sector rankings between two accounting methods. Figure 4 shows the variation trends in correlation coefficients for sector rankings by three accounting methods. An upward trend means that the sector rankings (indicating the importance degrees of sectors) between two methods are becoming more and more similar. On the contrary, a downward trend means that the difference in results between these two methods are becoming larger and larger. We observe a downward trend in the correlation coefficient between results of the income-based and production-based accounting methods during 1995-2009, indicating that there is an increasing separation between primary inputs (e.g., capital and labor forces) and GHG emitters along the global supply chains. Such an increasing separation validates the necessity of the income-based accounting method in identifying the importance of nation-sectors, in addition to the production-based accounting method. The correlation coefficient between the income-based and consumption-based accounting methods has a fluctuant trend during 1995-2009, and we observe similar situation between the production-based and consumption-based accounting methods during this period. This indicates that the separation status between primary inputs and consumption as well as between the production and consumption remains stable, with the average correlation coefficients as 0.6182 and 0.6245 , respectively.

Thus, the income-based accounting method can identify new critical nation-sectors leading to global GHG emissions which are unidentifiable in the production-based and consumption-based accounting methods, such as the renting and other business, wholesale and commission trade, and financial intermediation sectors. Supply-side policies are needed to guide primary input behaviors (e.g., limiting loan supply and subsidies $\underline{17}, \underline{18}$ ) and product allocation behaviors (e.g., promoting enterprises in these sectors to sell their products to less GHG-intensive downstream users $\frac{18}{}$ ) in these sectors. 


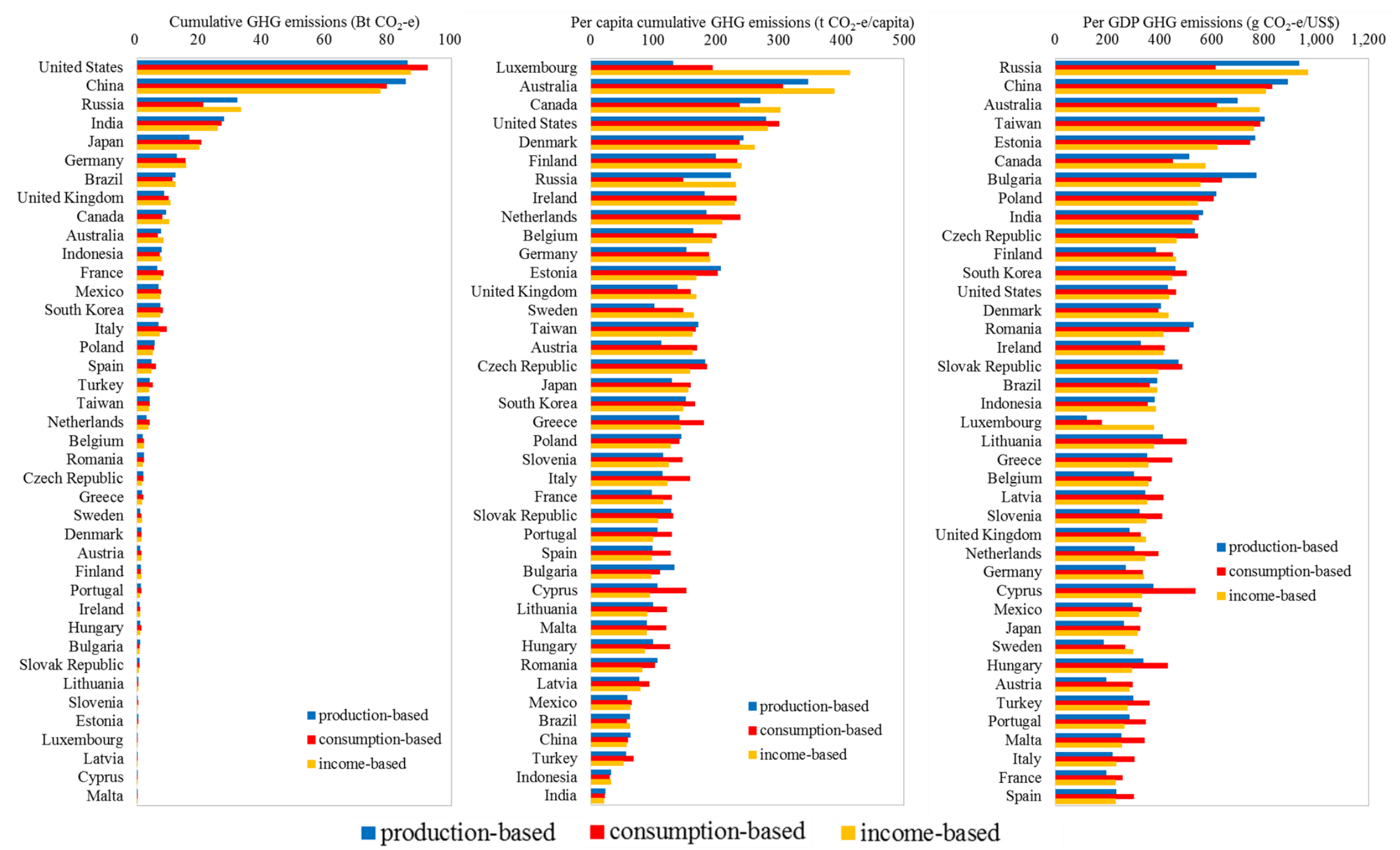

265 Figure 2. Cumulative GHG emissions of nations during 1995-2009. Per capita cumulative GHG emissions of a nation equal to its 
Cumulative $\mathrm{GHG}$ emissions ( $\mathrm{Bt} \mathrm{CO}_{2}$-e)

$\begin{array}{lll}0 & 20 & 30\end{array}$

RoW - Agricultur

RoW - Mining

USA - Electricity

China - Electricity

China - Agriculture

China - Mining

RoW - Electricity

India - Agriculture

USA - Renting and other business

USA - Mining

Russia - Electricity

Brazil - Agriculture

Russia - Mining

USA - Wholesale and commission

USA - Financial intermediation

USA - Agriculture

India - Electricity

RoW - Other service

USA - Inland transpor

China - Metals
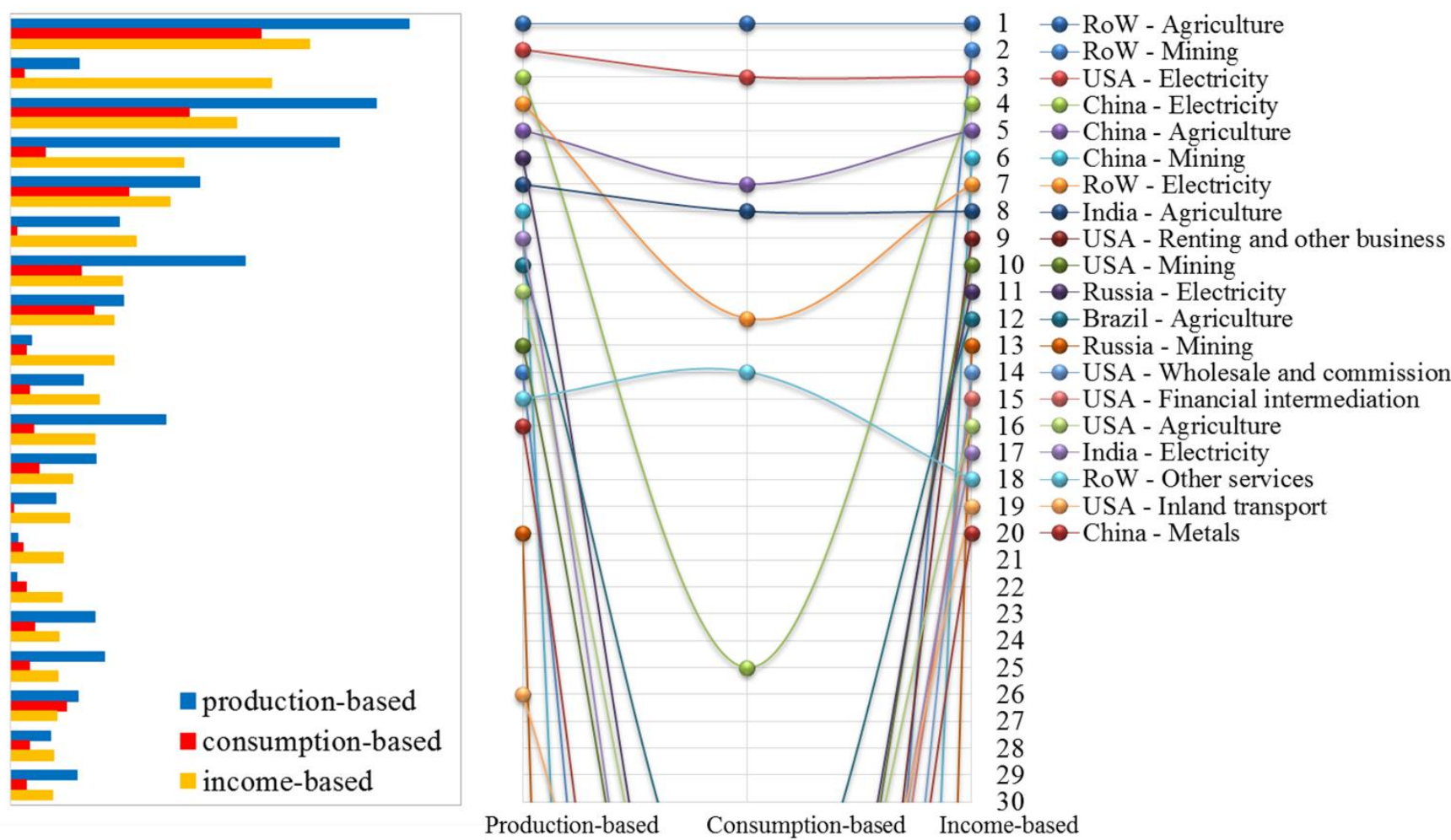

(A) Top 20 sectors in cumulative income-based GHG emissions

(B) Sectors ranking top 20 in cumulative income-based emissions

Figure 3. Top 20 sectors with the largest cumulative income-based GHG emissions during 1995-2009. RoW represents Rest of 270 World. 


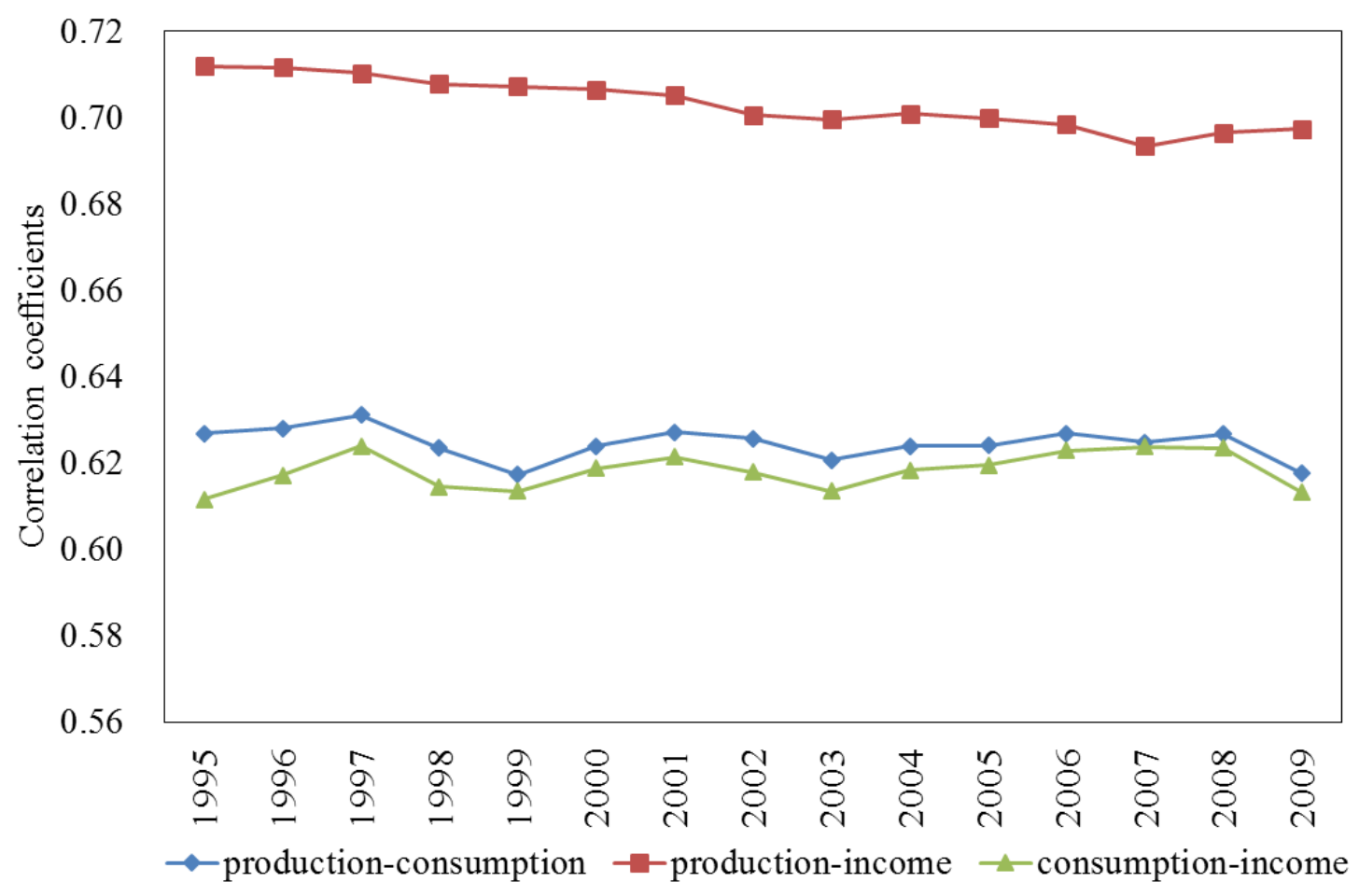

Figure 4. Temporal trends in correlation coefficients indicating the correlation of sector rankings during 1995-2009.

\section{TEMPORAL TRENDS IN INCOME-BASED GHG EMISSIONS OF NATIONS}

Income-based GHG emissions of developing nations keep growing during 1995-2009 (Figure 5), mainly due to their continuously increasing primary inputs (e.g., capital and labor forces) to promote economic development. Income-based GHG emissions of China, Indonesia, India, and Brazil in 2009 increased by 97\%, 74\%, 58\%, and 31\%, respectively, over 1995 levels (Figure S3). This increase is mainly driven by the rapid development of sectors producing basic materials (e.g., agricultural products, mineral ores and fossil fuels, metals, and electricity) and providing financial intermediation services (Figure S4). These products are essential to industrial production, and primary inputs to their production enable large amounts of downstream GHG emissions.

On the other hand, income-based GHG emissions of developed nations remain relatively steady during 1995-2009, except for Australia, Canada, and Luxembourg (Figure 5). Income-based GHG emissions of Australia and Luxembourg in 2009 increase by $41 \%$ and 60\% than 1995 levels, respectively (Figure S3). Income-based GHG emissions of Canada reached the peak in 2008 by increasing $33 \%$ compared to the 1995 level, and then dropped after 2008 under the global financial crisis.

It is worth noting that income-based GHG emissions of most nations, except for China and India, dropped after 2007 or 2008 , probably due to the influence of global financial crisis. The global financial crisis has little impact on income-based GHG emissions of China and India, reflecting its limited effect on capital investments in these two nations due to their strict capital control policies.

The income-based accounting method reveals different temporal trends in GHG emissions of nations (e.g., Australia, Canada, Germany, Japan, Russia, the US, and Luxembourg, Figures 5 and S3) over the 
production-based and consumption-based accounting methods. The rapid development of mining industries in resource-exporting nations (e.g., Australia, Canada, and Russia) drives their income-based GHG emissions (Figure S5). Income-based GHG emissions of these three nations remain higher than their production-based and consumption-based GHG emissions after 2002 (Figure 5), probably due to the increasing resource exports to emerging economies (e.g., China). Increasing resource demand of emerging economies in the future will probably further drive resource exports and income-based GHG emissions of resource-exporting nations.

Moreover, income-based GHG emissions of Germany keep higher than its production-based and consumption-based GHG emissions after 2001, due to the increase in downstream GHG emissions enabled by primary inputs in its renting and other business sector (Figure S6). Although Luxembourg has a small amount of GHG emissions in the world, the temporal trend in its GHG emissions is enlightening to global GHG mitigation. Production-based and consumption-based GHG emissions of Luxembourg keep steady during 1995-2009, but its income-based GHG emissions increased quickly in this period, especially during 2001-2007. The rapid increase in Luxembourg's income-based GHG emissions is mainly due to the increasing downstream GHG emissions enabled by primary inputs in its financial intermediation and renting and other business sectors (Figure S6). These two sectors have large primary inputs and income-based GHG emissions, but relatively few production-based and consumption-based GHG emissions (Figure S7). Such findings indicate that only concerning production-based and consumption-based GHG emissions of particular nations is not enough to mitigate global GHG emissions, if more developing nations switch to service-dominant economies (especially to renting and other business, financial intermediation, and wholesale and commission trade sectors). It is crucial for global GHG reduction to take into account income-based GHG emissions of nations.

The percentage decrease in income-based GHG emissions of Japan and the US is larger than that of their production-based and consumption-based GHG emissions (Figure S3). The decrease in their incomebased GHG emissions is mainly due to the decline in the downstream GHG emissions enabled by primary inputs in their renting and other business, financial intermediation, and wholesale and commission trade sectors (Figure S8). Such a finding can guide supply-side measures to focus on the reduction of income-based GHG emissions of these critical sectors.

Since population changes of nations are relatively small, temporal trends in income-based GHG emissions of nations on per capita basis (Figures S9 and S10) are similar to results on the quantity basis. This finding does not apply to the temporal trends on per GDP basis (Figure 6). Per GDP income-based GHG emissions of most nations, except for Indonesia and Luxembourg, have decreased during 19952009 , indicating the relative decoupling of supply-side GHG emissions of nations from their economic development. Income-based GHG emissions per GDP of Indonesia reached the peak in $2006(20 \%$ higher than 1995 level), while that of Luxembourg peaked in 2007 (30\% higher than 1995 level) (Figure S11). Although Luxembourg has lower per GDP production-based and consumption-based GHG emissions during 1996-2009 than 1995 levels, its per GDP income-based GHG emissions during 20032008 are higher than the 1995 level.

We find that the trends of nations' GHG emissions change under the income-based accounting method compared to the production-based and consumption-based accounting methods. On one hand, this finding reveals new trends in historical GHG emissions of nations, which provides additional information for responsibility accounting in global GHG reductions based on cumulative emissions of nations $\underline{42}, \underline{43}$. On the other hand, this finding reveals trajectories of income-based GHG emissions of different types of nations, informing potential drivers and hotspots for solutions. 

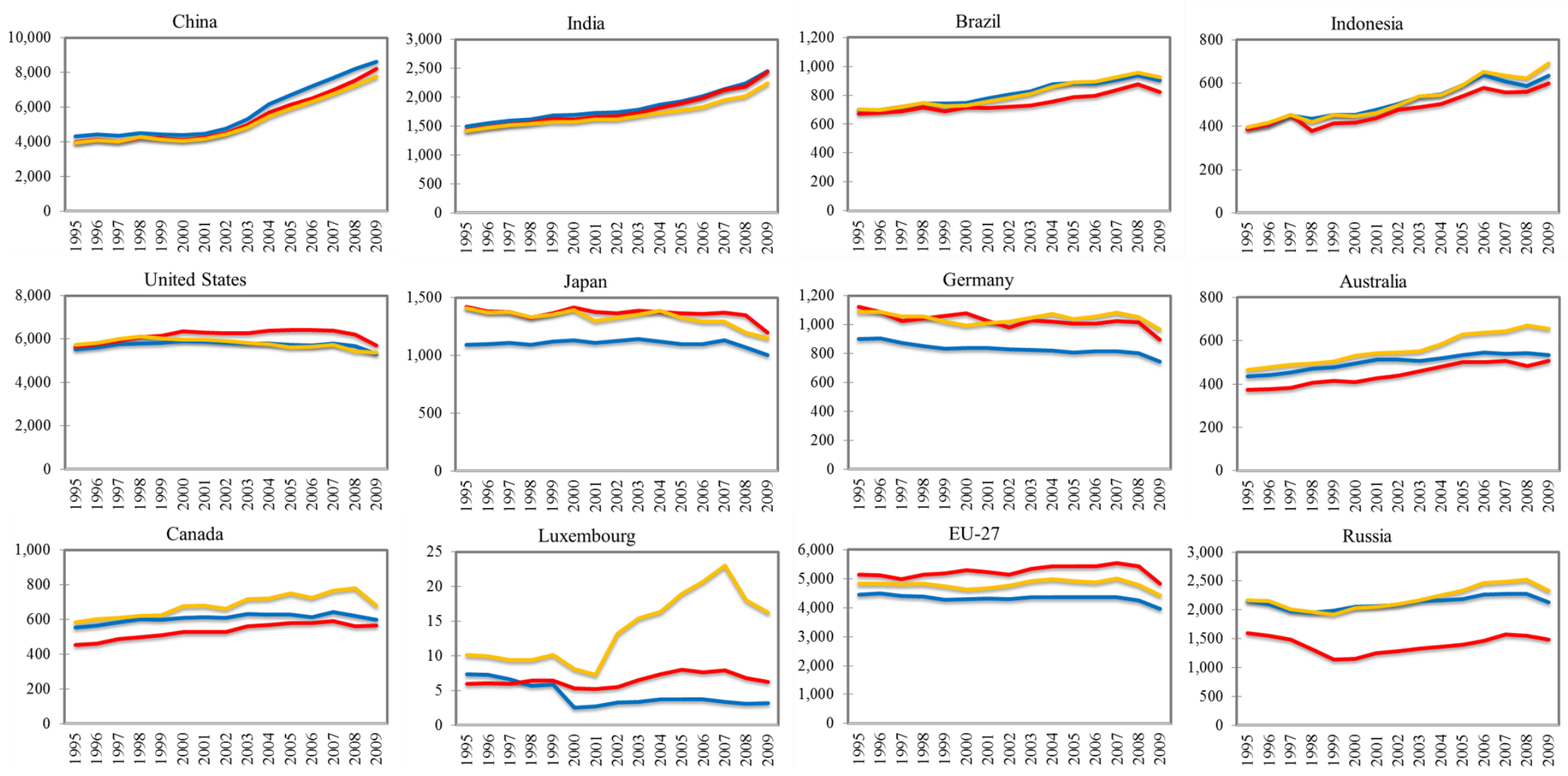

341 Figure 5. GHG emissions of nations during 1995-2009 (units: $\mathrm{Mt} \mathrm{CO}_{2}-\mathrm{e}$ ). 

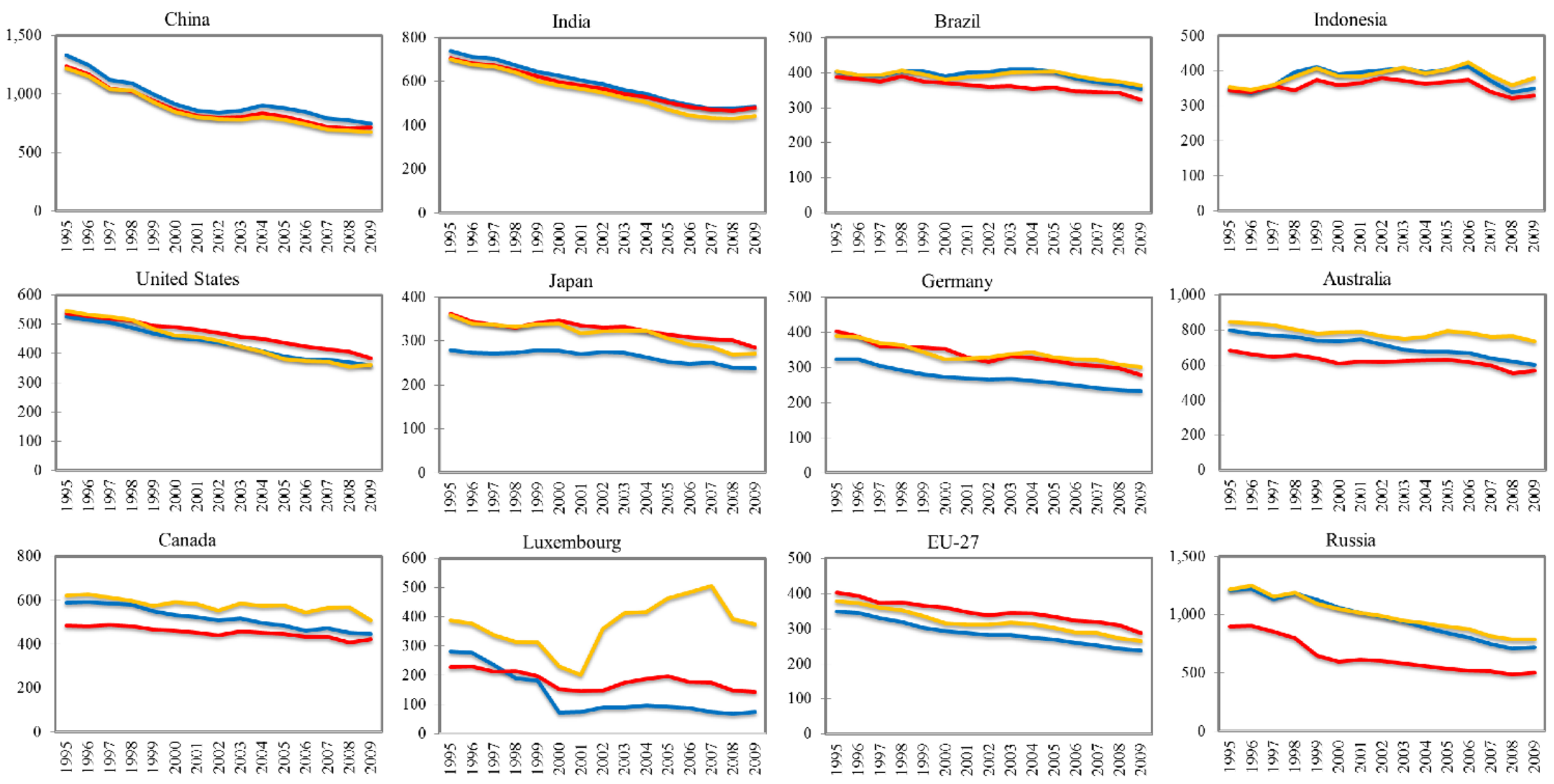

343 Figure 6. Per gross domestic products (GDP) GHG emissions of nations during 1995-2009 (units: g CO 2 -e / US\$). 


\section{DISCUSSION}

With the income-based accounting method, this study identifies new critical nations and sectors and new temporal trends which cannot be uncovered with the production-based and consumption-based accounting methods. The income-based accounting method can complement the production-based and consumption-based accounting methods to support policy decisions on global GHG mitigation, emission quota determination, and shared responsibility design.

\section{Supporting policy decisions from multiple perspectives}

The income-based accounting method implies different policy implications compared to the productionbased and consumption-based accounting methods. The production-based accounting identifies critical nations and sectors directly discharging large amounts of GHG emissions (e.g., electricity generation sector of the US and China). It informs policy decisions related to energy usage and end-of-pipe control (e.g., improving energy usage efficiency, promoting low-carbon energy sources, and implementing carbon capture and storage technologies). The consumption-based accounting identifies critical nations and sectors the final consumption of which induces large amounts of upstream GHG emissions (e.g., construction sector in China and public administration sector in the US). It informs policy decisions related to consumption behaviors (e.g., influencing consumption behaviors through carbon tax on consumed products) and international collaboration (e.g., transferring technologies and capital from final

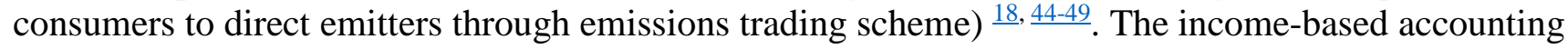
identifies critical nations and sectors primary inputs of which enable large amounts of downstream GHG emissions (e.g., the renting and other business, wholesale and commission trade, and financial intermediation sectors of the US). It informs policy decisions related to items in the value-added (e.g., adjusting the rates of taxes and subsidies on products and the rates of loans to the production) and product allocation behaviors (e.g., financial incentives on selling products to low-carbon users). Decision makers can choose to invest in dominant enterprises of sectors that have less income-based GHG emissions and limit loan supply and subsidies to dominant enterprises of sectors that have high income-based GHG emissions. Moreover, primary suppliers can reduce their income-based GHG emissions by selling to less GHG-intensive downstream users. For example, the US could encourage its financial intermediation enterprises (e.g., through government subsidies) to preferentially serve enterprises with lower GHG intensity instead of those with higher GHG intensity. Primary suppliers can also help reduce GHG emissions of downstream users with higher GHG intensity by transferring related technologies and capital investments to their downstream users (e.g., through emissions trading scheme).

The Carbon Disclosure Project (CDP) of the UK requires major enterprises to report GHG emissions

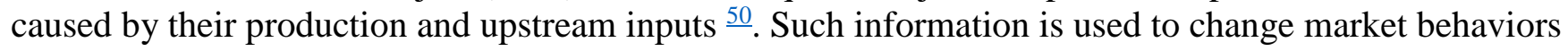
of decision makers. Encouraging an enterprise to trace GHG emissions of its downstream users in the CDP can help reveal its income-based GHG emissions. This is a promising way to implement supplyside policies discussed above. On one hand, this action can provide additional information for decision makers to change their market behaviors (e.g., capital investment). On the other hand, this action can help identify critical downstream users influencing an enterprise's income-based GHG emissions, supporting the choice of downstream users and emissions trading scheme. Similar measures should also be encouraged in mineral ore and fossil fuel mining enterprises of resource-exporting nations (e.g., Russia, Australia, and Canada), which are critical primary suppliers of the global GHG emissions.

Governments should reply on both administrative and economic tools to implement the production-side, demand-side, and supply-side measures. For example, administrative tools can be setting standards on GHG intensity of direct GHG emitters, embodied GHG certification of final consumers, and enabled 
GHG certification of primary suppliers. Economic tools can be using the rates of taxes, subsidies, and loans to influence product prices, consumption behaviors, and primary factor prices.

\section{Supporting emission quota determination}

Existing studies find that, to mitigate global GHG emissions, designing emission quotas based on cumulative emissions of nations may be more reasonable than simply on a particular year $\underline{42}, \underline{43}$. Timeseries analysis of income-based GHG emissions of nations in this study provides a foundation for determining quotas on cumulative emissions. Temporal trends in income-based GHG emissions of specific nations are much different from those in production-based and consumption-based GHG emissions. If quotas on cumulative emissions only consider production-based or consumption-based GHG emissions, the rapid increase of a nation's primary inputs in sectors with higher income-based GHG emissions than production-based and consumption-based GHG emissions (e.g., the financial intermediation sector of China) will still be responsible for the growth of global GHG emissions. Thus, results of the income-based accounting can be an important element in designing reasonable quotas on cumulative emissions.

\section{Supporting shared responsibility design}

Scholars propose that nations should share the production-based and consumption-based emission responsibility $\stackrel{2,8-10}{ }$. In addition to the production-based and consumption-based accounting methods, the income-based accounting method provides additional information on shared responsibility studies. If resource-exporting nations continue to export large amounts of resources to foreign nations, their income-based GHG emissions and the global total GHG emissions will increase, although their production-based and consumption-based GHG emissions may remain relatively stable. Thus, the income-based accounting method should also be taken into account by shared responsibility studies.

The Kyoto Protocol and Paris Agreement of the UNFCCC ${ }^{1}$ mainly focus on production-based GHG emissions of nations (e.g., emission reduction commitments and the emission peaking of nations), but pay little attention to consumption-based and income-based GHG emissions of nations. This situation will lead to emission leakages from final consumers to upstream suppliers and from primary suppliers to downstream users. Similar situation can be observed in GHG reduction actions of particular nations. For example, the US Environmental Protection Agency (EPA) proposed a Clean Power Plan (CPP) for $\mathrm{CO}_{2}$ reductions in existing power plants in $2015 \stackrel{51}{2}$. This CPP only concerns production-based $\mathrm{CO}_{2}$ emissions of power plants and states, while ignores consumption-based and income-based emission responsibilities of other sectors on the electricity sector. Incorporating demand-side and supply-side actions in other sectors can more effectively reduce $\mathrm{CO}_{2}$ emissions of power plants. Moreover, $\mathrm{CO}_{2}$ reduction goals of the US and China in the U.S.-China Joint Announcement on Climate Change $\frac{52}{2}$ only focus on production-based emissions of these two nations and ignore their consumption-based and income-based emissions. Similar situations are found in the UK's CDP and the $\mathrm{CO}_{2}$ reduction goals of China's FiveYear Plans.

Thus, the UNFCCC should count emission responsibilities of nations from multiple viewpoints such as the production, consumption, and income perspectives. This requires the development of hybrid approaches that consist of production-based, consumption-based, and income-based input-output models. The UNFCCC should also encourage nations to take shared responsibilities by making not only production-based but also consumption-based and income-based emission reduction commitments. This can enforce nations to take not only production-side but also demand-side and supply-side measures to control global GHG emissions. However, designing shared responsibilities is a challenging job. For example, assigning reasonable weights to multiple emission accounts is complex, because it must 
consider many relevant factors such as emission amounts, development levels, and the population of nations. Designing shared responsibilities is an important and interesting future research avenue. Future studies should also focus on the development of hybrid approaches that consist of production-based, consumption-based, and income-based input-output models prior to carbon cap or carbon quota policy making.

\section{SUPPORTING INFORMATION}

The supporting information provides supplemental Figures and Tables supporting the main text.

\section{REFERENCES}

1. UNFCCC United Nations Framework Convention on Climate Change (http://unfccc.int/2860.php). (September, 2016),

2. Peters, G. P., From production-based to consumption-based national emission inventories. Ecological Economics 2008, 65, (1), 13-23.

3. Babiker, M. H., Climate change policy, market structure, and carbon leakage. Journal of International Economics 2005, 65, (2), 421-445.

4. Peters, G. P.; Minx, J. C.; Weber, C. L.; Edenhofer, O., Growth in emission transfers via international trade from 1990 to 2008. Proceedings of the National Academy of Sciences of the United States of America 2011, 108, (21), 8903-8908.

5. Davis, S. J.; Caldeira, K., Consumption-based accounting of $\mathrm{CO} 2$ emissions. Proceedings of the National Academy of Sciences of the United States of America 2010, 107, (12), 5687-5692.

6. Kander, A.; Jiborn, M.; Moran, D. D.; Wiedmann, T. O., National greenhouse-gas accounting for effective climate policy on international trade. Nature Climate Change 2015, 5, (5), 431-435.

7. Springmann, M., Integrating emissions transfers into policy-making. Nature Climate Change 2014, 4, (3), 177-181.

8. Andrew, R.; Forgie, V., A three-perspective view of greenhouse gas emission responsibilities in New Zealand. Ecological Economics 2008, 68, (1-2), 194-204.

9. Gallego, B.; Lenzen, M., A consistent input-output formulation of shared producer and consumer responsibility. Economic Systems Research 2005, 17, (4), 365-391.

10. Lenzen, M.; Murray, J.; Sack, F.; Wiedmann, T., Shared producer and consumer responsibility — theory and practice. Ecological Economics 2007, 61, (1), 27-42.

11. Gereffi, G., Beyond the producer-driven/buyer-driven dichotomy: the evolution of global value chains in the internet era. IDS Bulletin 2001, 32, (3), 30-40.

12. Gibbon, P., Upgrading primary production: a global commodity chain approach. World Development 2001, 29, (2), 345-363.

13. Marques, A.; Rodrigues, J.; Domingos, T., International trade and the geographical separation between income and enabled carbon emissions. Ecological Economics 2013, 89, 162-169.

14. Marques, A.; Rodrigues, J.; Lenzen, M.; Domingos, T., Income-based environmental responsibility. Ecological Economics 2012, 84, 57-65.

15. Lenzen, M.; Murray, J., Conceptualising environmental responsibility. Ecological Economics 2010, 70, (2), 261-270.

16. Steininger, K. W.; Lininger, C.; Meyer, L. H.; Munoz, P.; Schinko, T., Multiple carbon accounting to support just and effective climate policies. Nature Climate Change 2016, in press, doi:10.1038/nclimate2867. 
17. Zhang, Y., Supply-side structural effect on carbon emissions in China. Energy Economics 2010, 32, (1), 186-193.

18. Liang, S.; Wang, H.; Qu, S.; Feng, T.; Guan, D.; Fang, H.; Xu, M., Socioeconomic drivers of greenhouse gas emissions in the United States. Environmental Science \& Technology 2016, 50, (14), 7535-7545.

19. Leontief, W., Quantitative input-output relations in the economic system. Review of Economic Statistics 1936, 18, 105-125.

20. Miller, R. E.; Blair, P. D., Input-output analysis: foundations and extensions. Cambridge University Press: 2009.

21. Wiedmann, T., A review of recent multi-region input-output models used for consumption-based emission and resource accounting. Ecological Economics 2009, 69, (2), 211-222.

22. Dietzenbacher, E., In vindication of the Ghosh model: a reinterpretation as a price model. Journal of Regional Science 1997, 37, (4), 629-651.

23. Davis, S. J.; Peters, G. P.; Caldeira, K., The supply chain of CO2 emissions. Proceedings of the National Academy of Sciences of the United States of America 2011, 108, (45), 18554-18559.

24. Dietzenbacher, E.; Los, B.; Stehrer, R.; Timmer, M.; de Vries, G., The construction of world input-output tables in the WIOD project. Economic Systems Research 2013, 25, (1), 71-98.

25. Timmer, M. P.; Dietzenbacher, E.; Los, B.; Stehrer, R.; de Vries, G. J., An illustrated user guide to the world input-output database: the case of global automotive production. Review of International Economics 2015, 23, (3), 575-605.

26. Myhre, G.; Shindell, D.; Bréon, F.-M.; Collins, W.; Fuglestvedt, J.; Huang, J.; Koch, D.; Lamarque, J.-F.; Lee, D.; Mendoza, B.; Nakajima, T.; Robock, A.; Stephens, G.; Takemura, T.; Zhang, H., Anthropogenic and Natural Radiative Forcing. In: Climate Change 2013: The Physical Science Basis. Contribution of Working Group I to the Fifth Assessment Report of the Intergovernmental Panel on Climate Change. Cambridge University Press: Cambridge, United Kingdom and New York, NY, USA, 2013.

27. WorldBank, World Development Indicators http://data.worldbank.org. In The World Bank: Washington, DC, USA, 2015.

28. DGBAS, Directorate-General of Budget, Accounting, and Statistics, Executive Yuan, R.O.C. (Taiwan) http://www.dgbas.gov.tw. In Taipei City,Taiwan (R.O.C.), 2015.

29. Lenzen, M.; Moran, D.; Kanemoto, K.; Geschke, A., Building Eora: a global multi-region inputoutput database at high country and sector resolution. Economic Systems Research 2013, 25, (1), 20-49. 30. Andrew, R. M.; Peters, G. P., A multi-region input-output table based on the global trade analysis project database (GTAP-MRIO). Economic Systems Research 2013, 25, (1), 99-121. 31. Tukker, A.; de Koning, A.; Wood, R.; Hawkins, T.; Lutter, S.; Acosta, J.; Rueda Cantuche, J. M.; Bouwmeester, M.; Oosterhaven, J.; Drosdowski, T., EXIOPOL-Development and illustrative analyses of a detailed global MR EE SUT/IOT. Economic Systems Research 2013, 25, (1), 50-70. 32. Arto, I.; Rueda-Cantuche, J. M.; Peters, G. P., Comparing the GTAP-MRIO and WIOD databases for carbon footprint analysis. Economic Systems Research 2014, 26, (3), 327-353. 33. Owen, A.; Steen-Olsen, K.; Barrett, J.; Wiedmann, T.; Lenzen, M., A structural decomposition approach to comparing MRIO databases. Economic Systems Research 2014, 26, (3), 262-283.

34. Liang, S.; Qi, Z.; Qu, S.; Zhu, J.; Chiu, A. S. F.; Jia, X.; Xu, M., Scaling of global input-output networks. Physica A: Statistical Mechanics and its Applications 2016, 452, 311-319.

35. Geschke, A.; Wood, R.; Kanemoto, K.; Lenzen, M.; Moran, D., Investigating alternative approaches to harmonise multi-regional input-output data. Economic Systems Research 2014, 26, (3), 354-385. 
36. Moran, D.; Wood, R., Convergence between the EORA, WIOD, EXIOBASE, and OPENEU'S consumption-based carbon accounts. Economic Systems Research 2014, 26, (3), 245-261.

37. Bouwmeester, M. C.; Oosterhaven, J., Specification and aggregation errors in environmentally extended input-output models. Environmental and Resource Economics 2013, 56, (3), 307-335.

38. de Koning, A.; Bruckner, M.; Lutter, S.; Wood, R.; Stadler, K.; Tukker, A., Effect of aggregation and disaggregation on embodied material use of products in input-output analysis. Ecological Economics 2015, 116, 289-299.

39. Lenzen, M., Aggregation versus disaggregation in input-output analysis of the environment. Economic Systems Research 2011, 23, (1), 73-89.

40. Su, B.; Ang, B., Structural decomposition analysis applied to energy and emissions: aggregation issues. Economic Systems Research 2012, 24, (3), 299-317.

41. Su, B.; Huang, H. C.; Ang, B. W.; Zhou, P., Input-output analysis of CO2 emissions embodied in trade: The effects of sector aggregation. Energy Economics 2010, 32, (1), 166-175.

42. Raupach, M. R.; Davis, S. J.; Peters, G. P.; Andrew, R. M.; Canadell, J. G.; Ciais, P.; Friedlingstein, P.; Jotzo, F.; van Vuuren, D. P.; Le Quere, C., Sharing a quota on cumulative carbon emissions. Nature Climate Change 2014, 4, (10), 873-879.

43. Wei, Y.-M.; Wang, L.; Liao, H.; Wang, K.; Murty, T.; Yan, J., Responsibility accounting in carbon allocation: A global perspective. Applied Energy 2014, 130, 122-133.

44. Feng, K.; Davis, S. J.; Sun, L.; Li, X.; Guan, D.; Liu, W.; Liu, Z.; Hubacek, K., Outsourcing $\mathrm{CO} 2$ within China. Proceedings of the National Academy of Sciences of the United States of America 2013, 110, (28), 11654-11659.

45. Zhang, Y.; Wang, H.; Liang, S.; Xu, M.; Liu, W.; Li, S.; Zhang, R.; Nielsen, C. P.; Bi, J., Temporal and spatial variations in consumption-based carbon dioxide emissions in China. Renewable and Sustainable Energy Reviews 2014, 40, 60-68.

46. Zhao, H. Y.; Zhang, Q.; Guan, D. B.; Davis, S. J.; Liu, Z.; Huo, H.; Lin, J. T.; Liu, W. D.; He, K. B., Assessment of China's virtual air pollution transport embodied in trade by using a consumptionbased emission inventory. Atmospheric Chemistry and Physics 2015, 15, (10), 5443-5456. 47. Liang, S.; Zhang, C.; Wang, Y.; Xu, M.; Liu, W., Virtual atmospheric mercury emission network in China. Environmental Science \& Technology 2014, 48, (5), 2807-2815.

48. $\quad$ Liang, S.; Wang, Y.; Cinnirella, S.; Pirrone, N., Atmospheric mercury footprints of nations. Environmental Science \& Technology 2015, 49, (6), 3566-3574.

49. Liang, S.; Guo, S.; Newell, J. P.; Qu, S.; Feng, Y.; Chiu, A. S. F.; Xu, M., Global drivers of Russian timber harvest. Journal of Industrial Ecology 2016, 20, (3), 515-525.

50. CDP, Carbon Disclosure Project: Driving sustainable economies (https://www.cdp.net). In CDP Worldwide: London, United Kingdom, 2016.

51. USEPA Clean Power Plan for Existing Power Plants

(https://www.epa.gov/cleanpowerplan/clean-power-plan-existing-power-plants). (September, 2016), 52. TheWhiteHouse, U.S.-China Joint Announcement on Climate Change (https://www.whitehouse.gov/the-press-office/2014/11/11/us-china-joint-announcement-climatechange). In The White House: Washington, DC, USA, 2014. 